\title{
HYDROELECTRIC ENERGY, REPRESSED DEMAND AND ECONOMIC CHANGE IN AMAZONIA
}

\author{
Rolf Sternberg *
}

\section{SUMMARY}

The economic activities that have been historically identified with Brazilian Amazonia required no inanimate energy. Extraction of forest products was managed with manual labor, so was placer mining. Steam powered machines and internal combustion motors became part of doing things in the context of time and space without conferring a measure of energy autarchy upon the region. Brazil's Amazon region, inspite of its physical wealth, could not mount a much needed infrastructure, It produced wealth without lasting benefits for the region. Amazonia, like the American prairie, had to await technological changes that make its careful utilization possible. One of these technological changes is hydroelectric energy. While hydroelectric energy will hardly be an exclusive agent of change, it will occupy a central position in reordering the human use of the land. It may provide the basic means for the much needed careful domestication of the land. Hydroelectric energy opens perspectives on Amazonia that invite rethinking about what is possible, desirable and necessary.

\section{INTRODUCTION}

Amazonia as concept and territorial fact is deeply and securely rooted in the Brazilian psyche. For Brazilian students of and practitioners in geopolitics the region has received detailed attention. It is in the socio-economic context that its integration into the Brazilian economy has been delayed by:

1. its distance from the dominant population centers;

2. inadequate communication links with the economic core until very recently;

3 . insufficiently trained manpower pools for integrated industries;

4. lack of adequate local capital to make effective use of the Amazonian resource base;

5. large internal distances in a sparsely peopled region;

(*) Paper Presented at 10th Meeting of The Latin American Studies Association ** Washington, DC, March 3-7, 1982

Department of Environmental, Urban and Geographic Studies Montclair State * College Upper Montclair, NJ 07043

This study has benefitted from much understanding help from a long list of professionals in Eletrobras, Eletronorte, SUDAM, OAS, SEPLAN, IDESP, and other offices. To them all I owe a great deal, and I can only hope that what is reported here is recognizable to them without a moment's hesitation. A note of special thanks for the released time granted by the Montclair State College community. 
6. random resource extraction without returning effective percentages of the net gains into the region.

Hydroelectric energy has to be placed into a regional as well as a national setting to assess its role in fostering local changes and the "interiorization" of Brazil. (See Section III below) The Tucurui hydroelectric power plant is not the first of its kind in Amazonia, but the first massive unit whose presence will have substantive consequences for the region. The consequences have to be considered under numerous headings as these are not solely economic, but extend into the social realm, educational system, cultural milieu, the environment, and the political life of the region. This analysis will seek to address some of these topics in their appropriate niche.

"Hydroelectric Energy, Repressed Demand and Economic Change in Amazonia" is predicated upon the premise that the introduction of hydroelectric energy will allow the formation of producing centers where none existed, further the growth of existing ones, and foster industrial development. With these changes emerges a measure of regional autonomy in the economic sphere that the region lacked until now. Inadequate energy supplies, which notably repressed the demand for it, hindered the growth of economic activities in the region.
The thrust of this analysis will focus upon the tentative role of hydroelectric energy in changing the regional economy of Amazonia. Initial changes will emanate from Tucurui, (see Figure 1) but other projects of this kind will be constructed in the foreseeable future in other parts of Amazonia to further the integration of the region into the national economy.

The construction of the hydroelectric power plant at Tucurui marks a divide between "then and now". This creation has to be set in the context of national and regional change, with emphasis upon the latter. Within such framework one has to consider a sequence of activities that contribute to alter existing conditions. First, the notable extractive economic activities, both of the past and the present; second, the growing awareness among Brazilian analysts of the region's geopolitical significance for the nation (Matos, 1980); third, the need to integrate the sub-populated lands effectively into the national economy, as well as to inventory the range of physical resources in the region to facilitate project planning; fourth, assess the impending changes that will follow increasing regional energy autonomy in established urban places as well as planned new centers of economic activities, and fifth, indicate the tentative outcomes of the interiorization of Brazil. 


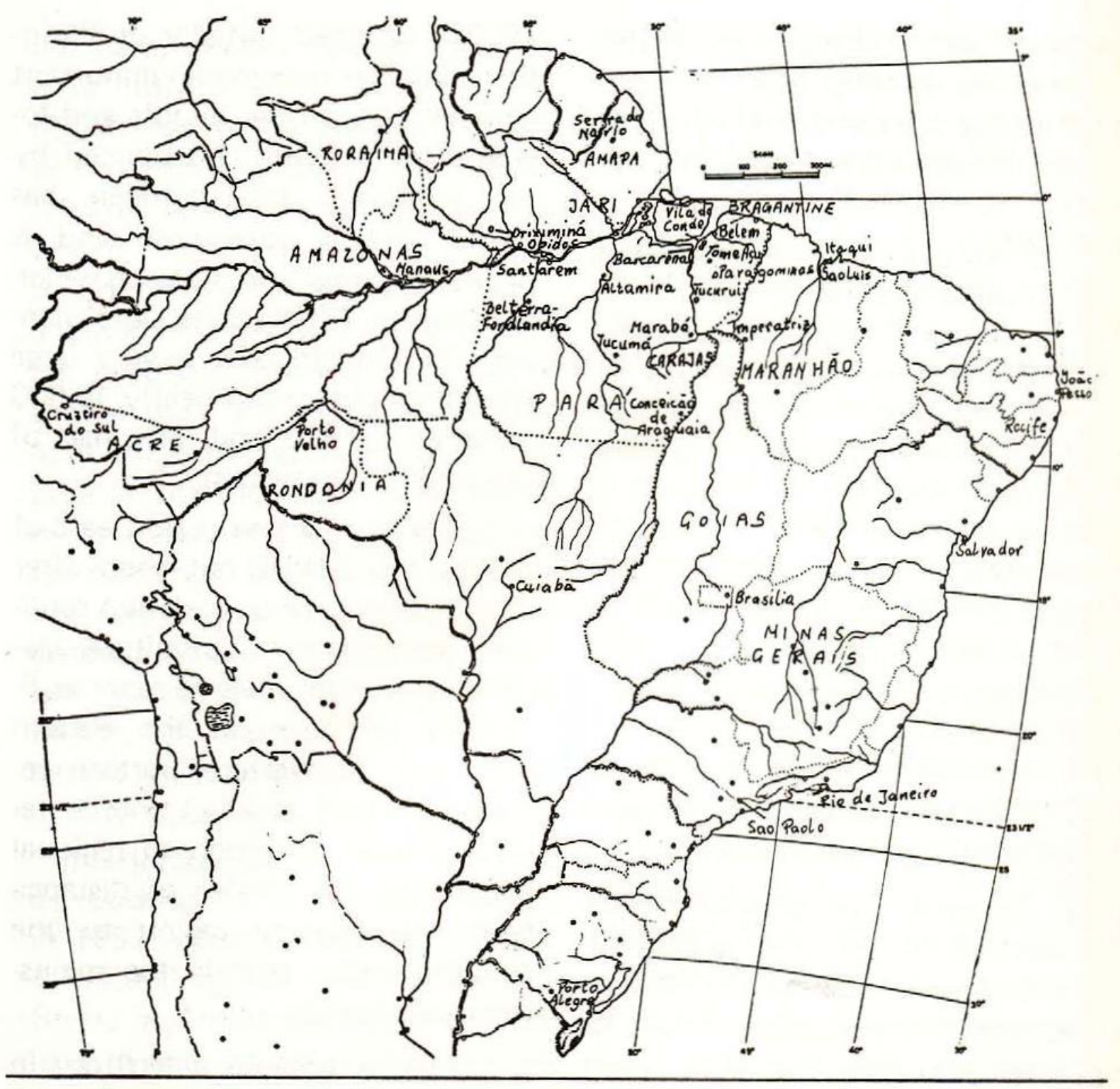

BRAZIL - FIG. 1 - Place Names

II. ANTECEDENTS TO THE INTERIORIZATION IN AMAZONIA

Woods, Brazil nuts and rubber are the better known products that have been staples in the Amazonian economy. Removal of these raw materials has been complicated by internal distance, lack of a large labor pool, and fluctuations in demand. Extraction of these resources did not lead to the formation of a network of transport arteries, numerous large urban places, and other features of a viable infrastructure. Little, if any, of the capital formed by these extractive activities was returned into channels that would further promoted economic growth in Amazonia. Resources and returns left the region without any notable multiplier effect. This onesided flow of resources, by no means uniform because of fluctuations in 
seasonal yields, changing marketing, and other vectors, acted as a barrier to the interiorization of the region. Things were moved out, not in.

Ford and rubber are identified with Fordlandia and Belterra. There on the lower Tapajoz, the location and the available labor supply seemed promising, providing a basis for a positive outcome. This project may have engendered optimism in Rio de Janeiro or São Paulo (also in Deerbon), at the time of its implantation (1928), however, locally it had no multiplier effect and never advanced to the level of innovation diffusion pole. Though this might have become an "interiorization pole," it was left to vegetate and even now remains at best as a portal.

Japanese immigration stands in contrast to the other occupants of the region. Japanese immigrants who settled in the region lacked financial resources and they were virtually without options to relocate readily. The largest concentration of Japanese settlers rooted in Tome Açu, where pepper cultivation, rice, jute and other crops became key products. In general, the 50 -year history of the Japanese in the region is an achievement in terms of permanence, but this has not been widely duplicated. Their role in the "interiorization process" has been limited rather than propagative.

Jute planting came to the middle Amazon region in the early 1930's, centered initially on Parintins. This has become an important regional crop in the middle and lower Amazon basin. Introduced by the Japanese, this cultigen has found general acceptance and is planted on small holdings on which it occupies 2-3 hectares. Jute plantings are spread over a very large area; they comprised nearly 45,000 hectares in 1970, and form part of the varzea crop system.

The Bragantine region east of Belém was settled, but soon after deforestation soil degradation set limits to productive agriculture. Marajó Island continues to serve as livestock producer in the eastern half, and its western portion remains a forest product source region. Uneven attention to regional needs plus the barrier of distance kept the gateway region to the Amazon basin outside the mainstream of change.

Amapá became a territory in 1943, when it was separated from Pará state. Manganese was discovered in 1947, but another ten years would pass before the ore became available for extraction and export. By 1957 the mine came on stream, after a railroad linking Porto Santana with Serra do Navio was completed. Shortly thereafter two urban centers were completed to serve the working population of this enterprise with a sophisticated urban infrastructure. ICOMI, as the concern in known locally, provided and provides most of the territory's 
tax base, but no notable activities were introduced by other firms. ICOMI eventually associated itself with a Dutch group to form BRUMASA, which transformed local woods into plywood and other by-products for export. Throughout this time, 1947-1981, ICOivil has been the financial mainstay of the territory and continues to be so as it is expanding its activities into pine for cellulose, palms for dende oil, and has plans for cacao and coffee plantings. These latter activities will come on-stream when the manganese production will cease, five to ten years hence. This would then be the first major step at "interiorization" in Amazonia.

A more grandiose scheme of "interiorization" was initiated by Ludwig, National Bulk Carrier, in 1967, when he purchased some $1,400,000$ ha. of land on the Jari River, in Amazonia. Somehow, the idea of the project is plausible, attractive and possible. The enterprise overcame many environmental challenges, but found the human element in the end beyond its managerial skills. Much has been accomplished, according to well-informed sources. Now the project has become a national enterprise and if the original momentum of activities can be partially regained, this could become a major model of how to use and conserve the Amazonian environment.

Tucumá is a colonization project in southeastern Pará (see Figure
2 ), in the county of São Felix do Xingu. This agricultural colonization project is being mounted on a 400,000 ha. area east of São Felix do Xingu and southwest of the Carajás project by the Construtora Andrade Gutierrez, S. A., a major Brazilian construction firm. At this time the plan is to settle $3000 \mathrm{fa}$ milies who will engage in agriculture and transform the project into a complementary development pole in relation to the other poles in progress: Carajás, Tucuruí and Marabá. “No Pará está nascendo um novo Brasil" "In Pará a new Brazil is being born." (Construtora A. Gutierrez, 1981). Plans call for completion of the settlement process in six years. Fifty percent of the area is to go into an ecological reserve, "forest reserve". Agricultural activities are projected on the basis of land quality as follows:

1. horticulture and fruit plantings on lots ranging in size from 15 to 55 ha. each;

2. general agriculture on units to range from 55 to 280 ha. each;

3. livestock units to range in size from 280 to 600 ha. each.

The Krimet experiment station serves to identify the best strains and most important crops for the region, namely: cacao, rubber, guaraná, black pepper, rice, corn, bananas, citrus, coffee, beans, papaya and general garden crops. 


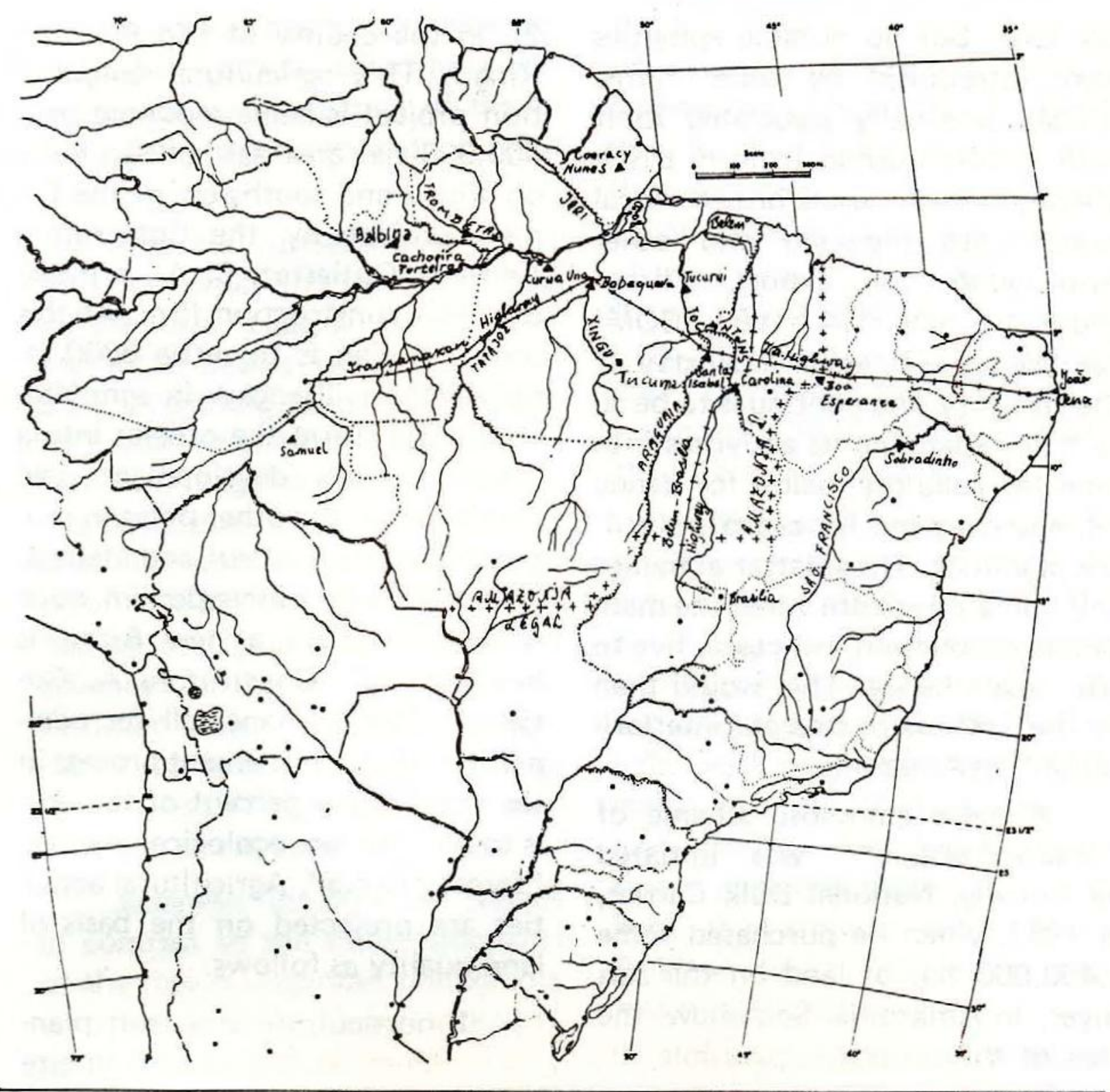

BRAZIL - FIG. 2 - Infrastructure-Projects

The foregoing examples serve as guideposts to varied efforts to bring Amazonia into the economic mainstream of Brazil. The halting changes are indicative of the magnitude of the challenge and the effort needed to affect movement toward "interiorization" of the region. One may think that all that is needed is people and capital, but perceptions and policies play their part in such enterprises. Perceptions and policies are subjective vectors that often form a labrynthine maze that only posterity can appreciate in its totality.

III. INTERIORIZATION-GEOPOLITICAL CONSIDERATIONS

Isolation conferred a certain measure of insulation upon Amazonia. Brazil's Amazonian boundaries evolved over four centuries and their present configuration can be 
considered completed by 1907 when the treaties with Colombia and Venezuela were signed. Completion of the exterior limits was not accompanied by interior consolidation of the region. Amazonia was described as a "hollow frontier" (James, 1969) a characterization that requires time and effort to change, a process that has been initiated. Brazilian geopolitical students (Matos, 1980) have recognized the importance of the region in their writings, but the implementation of some of their suggestions had to await the convergence of numerous features such as population growth, transport technology, world resource markets, and a national consensus to bring the region into its mainstream. The turning point in this process can be identified with the relocation of the federal government from Rio de Janeiro to Brasilia in 1960, and the construction of the Belém - Brasilia highway. These two changes can be viewed as essential first steps to move from "de jure" to "de facto" control of the region.

The nation's future and strategic needs resulted in the re-examination of Amazonia in the national context in 1954. Development needs and national cohesion led to the creation of the planning agency that preceded SUDAM, namely SPVEA, or the Development Agency for Amazonia. (Reis, 1956). Extensive areas with a sparse population have to be planned for. The economic aspect of Amazonian changes have been in the care of SUDAM since 1967, the successor agency of SPVEA. Projects have been organized in isolation without turning into centers of expanding change. This is changing, but the magnitude of the region disguises the actual pace of diversification.

Strategic needs of a more traditional kind have been combined with economic development to serve the nation and territorial unity. The network of roads that has been created in Amazonia since 1970 is considerable. (Fig. 2) It is possible ro reach Manaus by bus from Porto Alegre via Porto Velho, travel overland to Santarém from Brasília, or get to Cruzeiro do Sul from São Paulo. The Brazilian road system thus improved territorial unity and reduces the friction of space facilitating the "interiorization process", while linking the farthest frontier points to the economic core of the nation.

Another preparatory measure to achieve more effective "interiorization" of the nation was the radar survey of Amazonia, known as RADAM. RADAM provided a first comprehensive" mapping program for Amazonia, which included soil, vegetation, terrain, and land capability analysis. The results of this work have been used to build the roads into Amazonia, organize the colonies along the Transamazon, provide SUDAM with base maps for its 
development projects, which can also be said for Eletronorte and its many inventory projects in the region, as well as numerous other activities. (1)

Geographical perspectives have a way to be holistic. This is also the case in Amazonia. Reference has been made to human and technical facets without much attention to the physical resource base of the region. The total extent of all physical resources in Amazonia remains to be identified, but by 1981 enough was known that reference is made and plans are in progress that will make eastern Amazonia an integral part of the Brazilian economy. When $\$ 60,000,000,000$ are to be invested in a very limited area within ten years, a very different way of doing things is at hand. Mineral resources and their processing by large firms, state-owned and private, will lead to the formation of local industries that draw large cash flows from the "center" to the onetime "periphery". The key planner in these changes is the federal government, which is also indicative of the strategic motivations that are fundamental to achieve an effective measure of "interiorization" for the national economy. The key factor in this development has been the iron ore of Carajás. Possibly one of the precipitators for this change is the bauxite deposit of Oriximiná, nor should the enormous bauxite deposit near Paragominas be passed over. The sum of this can be described as a fantasy in 1974, not in 1984, except for a select few who knew what was in the offing.

At another level, the "interiorization" of Brazil is continued in a more traditional way by migrant farmers to what is termed the frontier. These farmers are being bought out, or as farmhands lose their livelihood in the three southern states to the soybean producers. These one-time farmers or farmhands leave the area and migrate into Rondonia or Acre, thereby creating a prong of sorts in the "interiorization" process. Reports from Rondonia indicate that the population of the state has increased from the 1970 census year to the 1980 census by $431 \%$, with most of the arrivals entering in the last five years. The "município" of Ji-Parana grew from 9136 persons in 1970 to 124,278 in 1980 , or by $1360 \%$. (IBGE, 1981). Isolation of the past gives way to national integration at numerous levels. Some of the geopolitical considerations become reality in a spontaneous course rather than a carefully prescribed one.

\section{HYDROELECTRIC ENERGY, REPRESSED DEMAND AND ECONOMIC CHANGE IN AMAZONIA}

How can one explain this heading in virtually one breath? When

(1) One should include the professionalism that evolved with this project, as well as the analytic survey volumes that have been published since 1973 . 
energy is rationed on a rotating schedule for neighborhoods in $\mathrm{Be}$ lém or Manaus, or when it is not generated at all in smaller interior cities such as Marabá, Conceição do Araguaia, Altamira, Paragominas, Tome Açu, etc., that in brief is "repressed demand". The absence of a locally existing dependable energy supply system results in repressed demand as soon as activities depending upon energy have to interrupt operations because of inadequacies in the energy supply system. Given such conditions, economic change has to abide uneven rhythms imposed upon the production cycle. This condition arose in part from the growing dependence upon hydrocarbon generated energy, and in part because of accelerating growth rates of population in the region's urban centers. Conditions were aggravated by rising petroleum prices and import reductions. It is in this setting that the creation of a hydroelectric energy system has to be assessed for its impact upon life and livelihood in Amazonia.

Hydroelectric energy is a relative recent entry to the Amazonian realm. Its initial entry is at Curuá-Una, about $70 \mathrm{~km}$ east of Santarém. (2) This power plant has a potential to generate $40 \mathrm{MW}$ at maximum capacity. In 1980, only two $10 \mathrm{MW}$ turbines were operational, while work was in progress to place the remaining two $10 \mathrm{MW}$ units. Once these two units enter operation, much of their energy is destined for a cement plant that is to be located in the Santarém sphere of influence. This is tentative, but that it is considered indicates the energy dependence of industry in this region. The hydroelectric plant has brought a measure of energy autonomy to Santarém and umland, which is a novelty for Amazonia. Curuá-Una is a local rather tham a regional facility, hence its impact is areally limited.

Curuá-Una is a model that has provided a lesson that is being taken very seriously by the hydroelectric sector, namely its environmental impact. Reservoir formation was followed by putrification of the water and the loss of aquatic life because appropriate deforestation was not carried out. The Curuá-Una experience has influenced the management of Eletronorte to make detailed surveys and plans for reservoir clearance, which it has to coordinate with other government agencies.

Curuá-Una and Coaracy Nunes are the antecedents of Tucuruí Dam, in progress since 1976. (See Photos 1-3). This may be considered the first major dam in the region that will allow the creation of a major energy shed. Present plans anticipate installed capacity of

(2) The other operational hydroelectric power plant is on the Araguari River in Amapá, some $45-50 \mathrm{~km}$ east of Porto Platon. Coaracy Nunes, with a potential for $100 \mathrm{MW}$. 


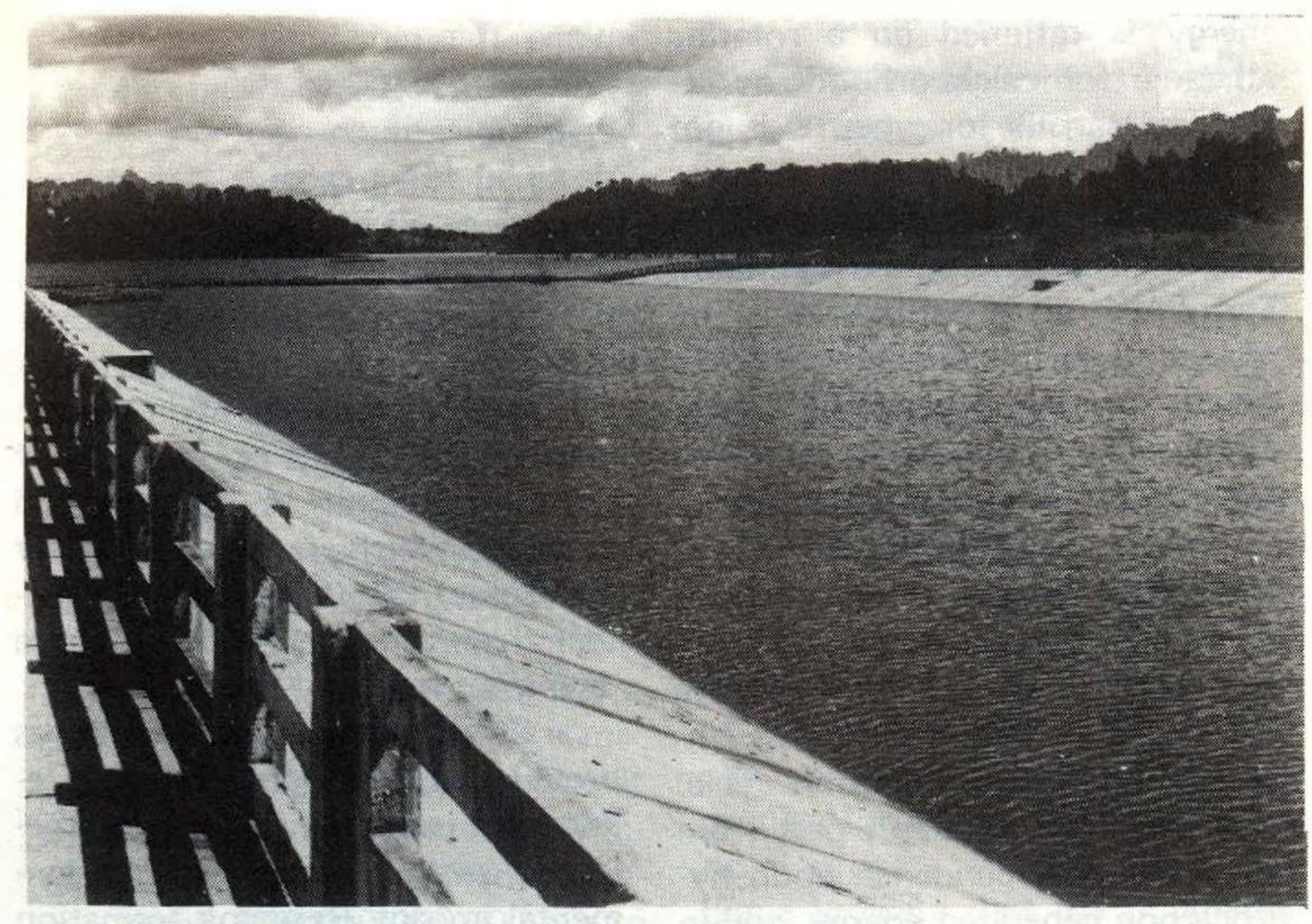

1. Curuá-Una reservoir looking upstream with forest background, including pontoon bridge to reduce water hyazinth access to powerhouse water intake. (Photograph by Frances Sternberg).

$8000 \mathrm{MW}$, to be built in two phases, the first segment for 12 turbines of $330 \mathrm{MW}$ each to be completed by late 1984, the second to be carried out some five to ten years hence. The two-phase plan is conditioned by the Tocantins River as several upstream dams have to be installed prior to completing Tucuruf proper. The initial phase of this project includes energy for São Luis in Maranhão, Belém, Marabá, Imperatriz and eventually $\mathrm{Al}$ tamira. The mere reach of the projected power grid allows for changes that will contribute significan- tly to the "interiorization" of the region (see photos $4-7$ ).

Tucuruí has advanced the "interiorization" process in Amazonia. The Transamazon highway is a necessary antecedent, so is the Belém-Brasília road, which grew out of the transfer of the capital to Brasilia in 1960. Implantation of a functional infrastructure in Amazonia has progressed at a considerable pace, even though it is confined in scope at present, a condition that is apt to be changed at an accelerating rhythm as the energy system in the region grows in extent. If Tucu- 


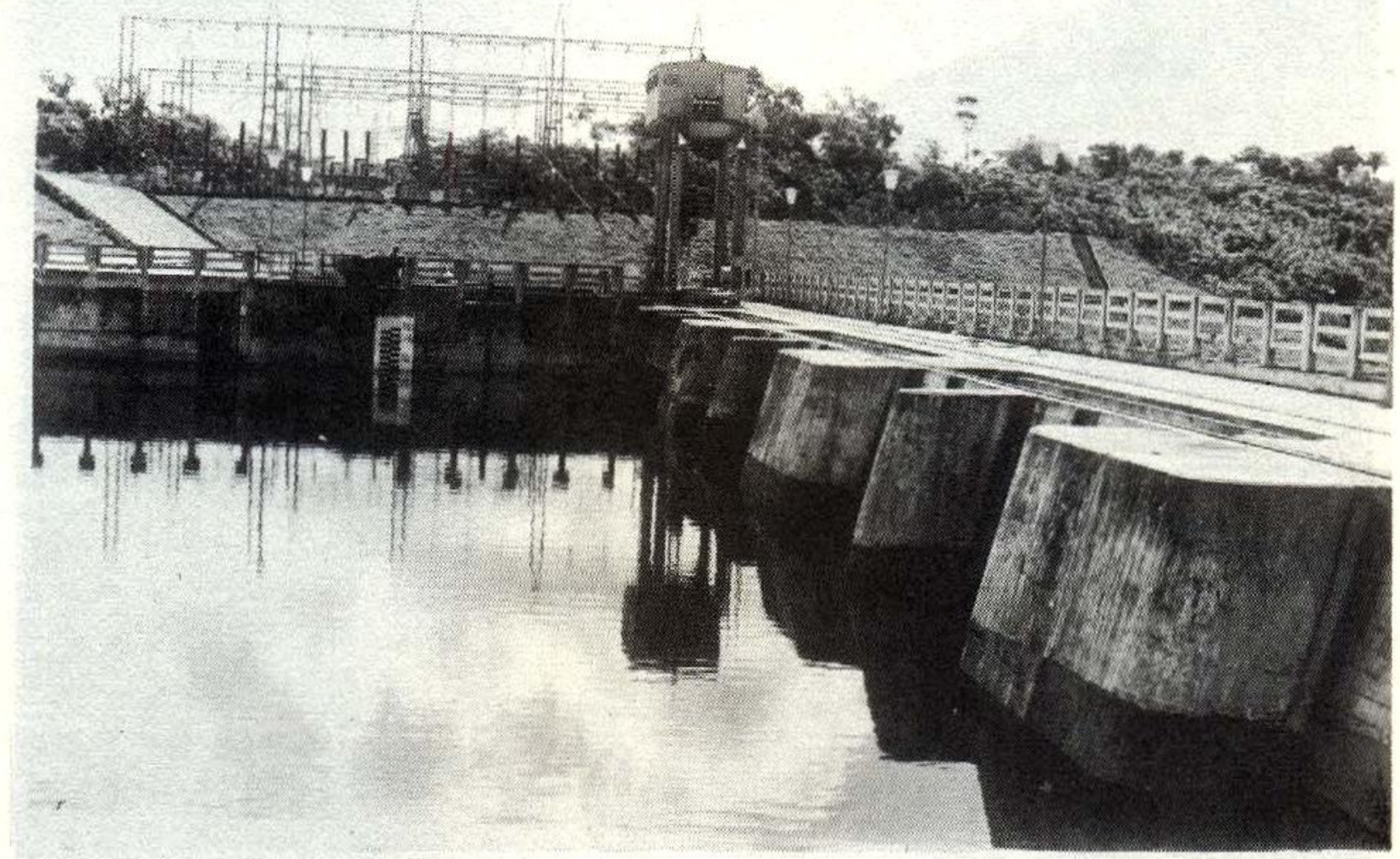

2. Curuá-Una - powerhouse water intake area. Transmission system in background. (Photograph by Frances Sternberg).

ruí is the point of penetration, Balbina near Manaus and Samuel near Porto Velho are other hydroelectric projects under way or about to begin to use energy as an instrument of change in more isolated settings. Another planned project of this genre is Cotingo I, $60 \mathrm{MW}$, near Boa Vista, Roraima. These smaller dams are known as "social dams." Dependence upon river transport will decrease as will the need to import costly petroleum to generate thermal energy. Tucuruí energy is slated to power the railroad from Marabá to Itaqui. Aluminum and steel producing facilities will be powered by hydroelectric energy.
The kind of economic activities will be very different henceforth from those identified with the region until now. The local economies will sustain notable changes in emphasis resulting in a very different order upon the land.

A brief comparison of roads and hydroelectric power projects in the Amazonian "interiorization" process may be instructive. The Transamazon road created a narrow belt for swift access into the onetime inaccessible interior of Amazonia. It served government and people to gain ready entry into a region previously isolated from the rest of the nation via land. In contrast to 


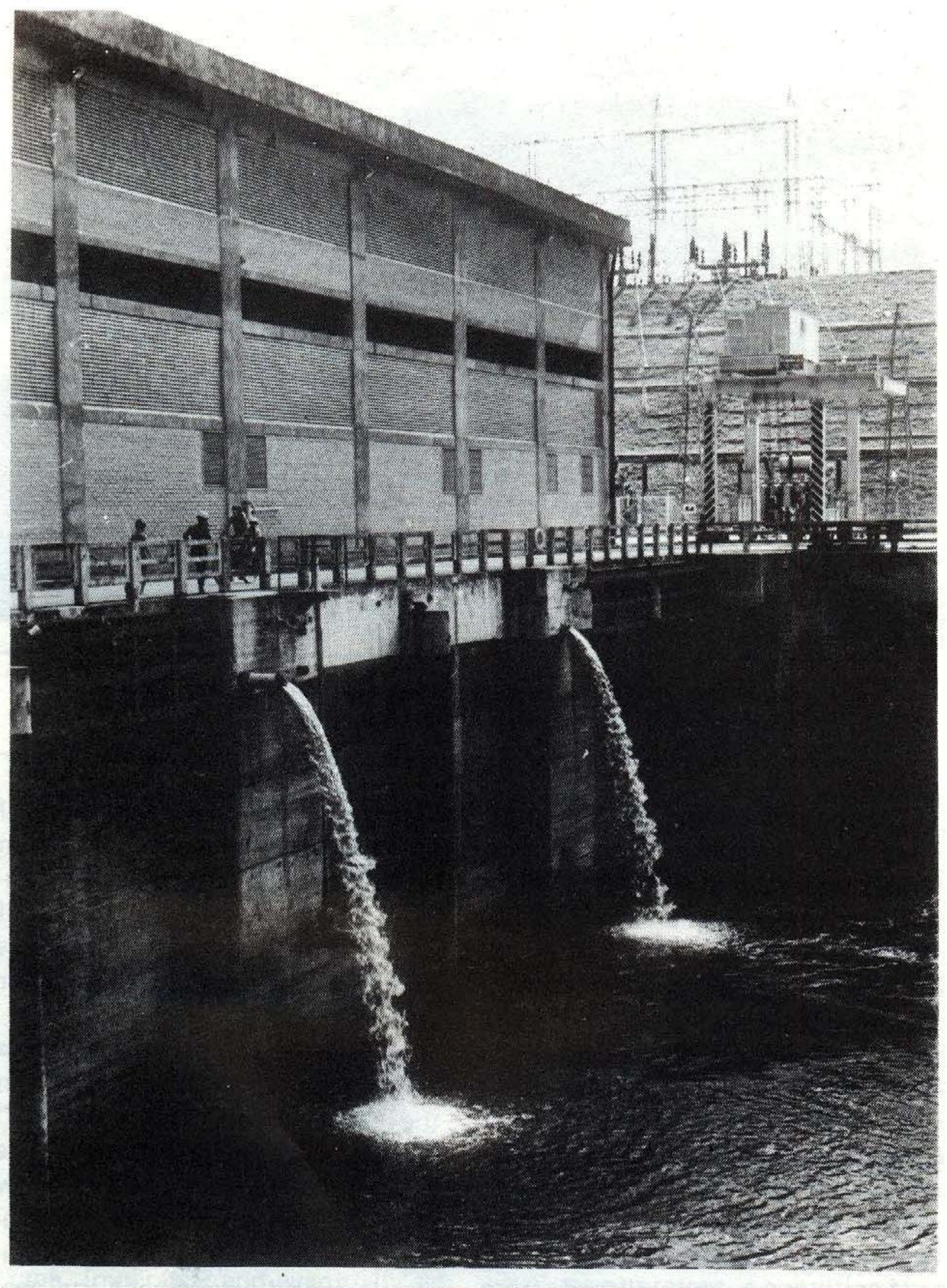

3. Curuá-Una - downstream side of powerhouse with transmission system. (Photograph by Frances Sternberg). 


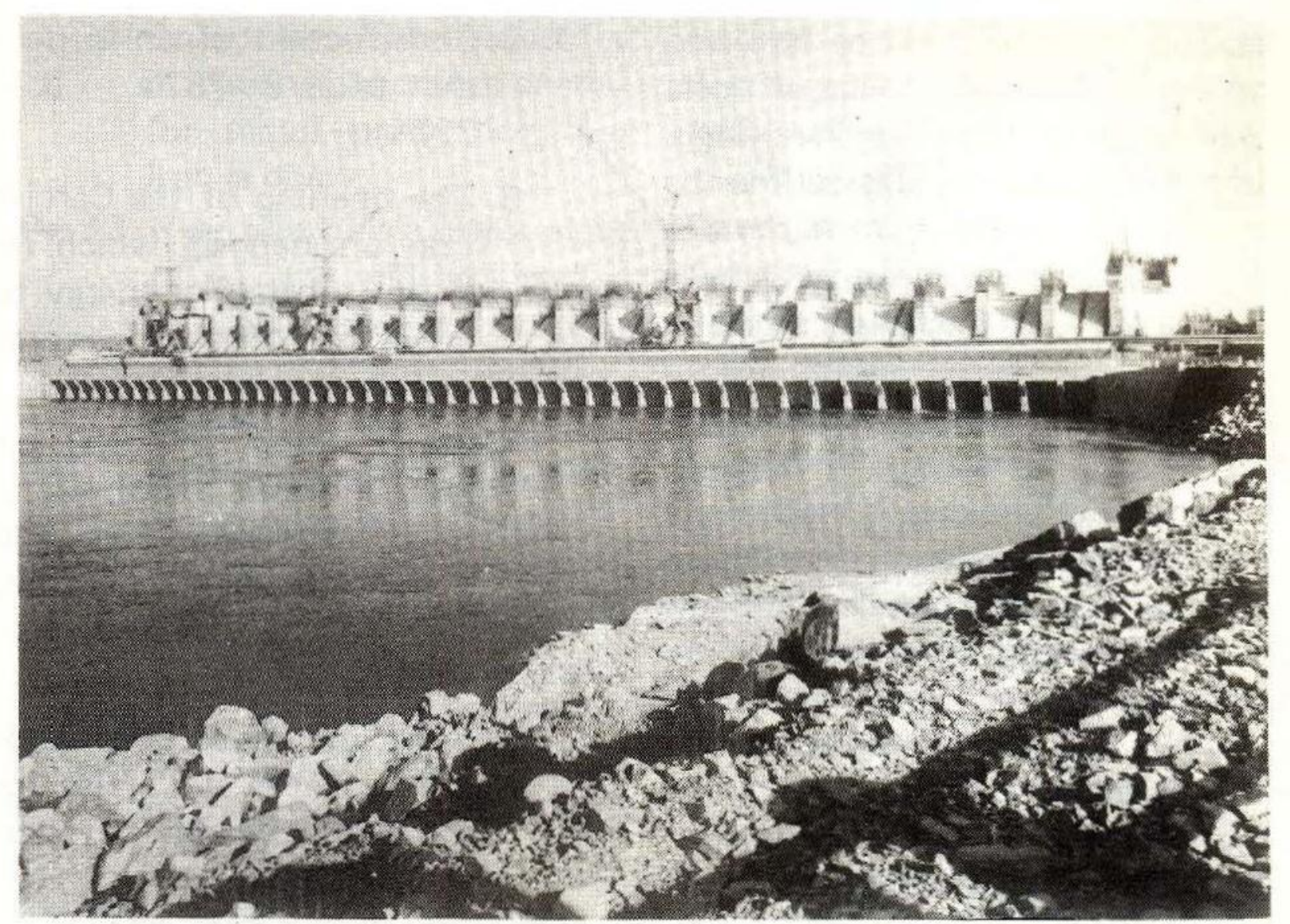

4. Tucurui - Spillway-downstream view. This is the world's largest spillway to date; it can manage up to $100,000 \mathrm{~m}^{3} / \mathrm{s}$. (Photograph by Frances Sternberg).

roads, hydroelectric power plants cannot offer such immediate benefits. Their implantation and their functional purpose follows a different schedule and serve very different objectives than roads, though complementary, it in certain aspects can be identified. Urban places follow road formation, in the case of hydropower plants they have to precede, as project community, and once the plant is completed much of the town becomes available for changed functions. Hydroelectric projects tend to create urban places and draw people into their orbit, highways, on the other hand, link places and ease population movement along their path from the lesser to the larger centers.

If only the next few projects of Eletronorte are considered, which is the government's agency to oversee hydroelectric energy management in the Amazon region, the "interiorization" process will be shaped in large part by this regional organization. The next major project is Santa Isabel dam, (1970 MW) (see Figure 2), on the lower Araguaia, followed by Carolina on the middle Tocantins (2227 MW), both major projects, which are preconditions to complete the second phase 
of Tucurur. These will be followed by the $14,000 \mathrm{MW}$ project of Volta Grande at Altamira on the Xingu. In the later years of this decade the upper Tapajós will become the site of several dams to service the Cuiabá region, and Cachoeira Porteira (1450 MW) on the Trombetas to provide for change around Oriximiná-Óbidos and eventually Manaus, since the Balbina dam is inadequate to meet the city's and region's projected energy demand. The projects in the Tocantins-Araguaia basin are antecedent to a possible reshaping of Goiás and making it a major corridor of change in Brasil. Roraima and Amazonas will be involved, but not on the scale of change that will come to Pará.

Tucurur will occupy a key position in the "interiorization" process of eastern Amazonia. The investment in the project exceeds $\$ 6,000,000,000$, excluding interest payments during the construction period. (3) This initial investment has set in motion a plan to spend $\$ 60,000,000,000$ during the next 10 years, 1982-1992, in Carajás and associated projects in this part of Amazonia. Tucurui dam provides the pre-condition for the following changes in its sphere of influence:

1. A planned community, now the home for the power plant employees, of nearly 30,000 .
2. Construction of an airport that takes B-737's, B 727's;

3. The opening of the Carajás iron ore deposit, which requires substantial energy to move iron ores, copper ores and managanese, initially.

4. Construction of a $900 \mathrm{~km}$ railroad from Itaqui, Maranhão, to Marabá, Pará, and a feeder to the Carajás hills, $170 \mathrm{~km}$ to the west, southwest.

5. Construction of two major urban places at Carajás for an estimated 65,000 persons initially;

6. A projected branch railroad to link the Paragominas (Caru-Piquiá) bauxite deposits to São Luis (these exceed $2.4 \times 10^{9}$ tons proven).

7. A high voltage line to Paragominas to serve a bauxite transforming facility;

8. To reshape the function of Marabá and create an industrial center in the one-time "castanha do Pará" capital;

9. Marabá will become the region's transport node.

10. At Vila do Conde ALBRĀS and ALUNORTE will open major bauxite processing plants.

(3) The first twelve turbines will bring the cost/.kw, to $\$ 765$, but the second set is projected to cost $\$ 485 / \mathrm{kw}$ installed. 
11. One or two metal industries in Tucuruí, to utilize energy for metal production, pig iron is one.

12. Near São Luis a major plant of ALCOA will be installed to process bauxite from Oriximiná and Paragominas;

13. Belém will be free of the previous constraints of energy supplies and have the potential to become a major regional industrial center.

14. At São Felix do Xingu cassiterite will be extracted;

15. Agriculture will undergo changes because of changed market conditions.

The above is a most general outline of the initial changes. Reality has a way to alter and modify projections. Not to be overlooked in this connection is the substantial increase in the Brazilian population, the domestic market, and the bi-po- lar iron ore resource base. It would not surprise one if the CVRD (Companhia Vale do Rio Doce) would'use the Minas Gerais iron ore deposits for domestic use exclusively and use the Carajás iron ores mostly for export instead. This would be a form of decentralization and "interiorization" at the same time. The implications of large capital shifts will take time to imprint themselves as economic patterns upon a hitherto sylvan landscape.

The largest users of hydroelectric energy will be the bauxite processors ALBRAS, ALUNORTE and ALUMAR (ALCOA). The latter has a dock-site location in São Luis, while the first two are constructing their industrial plants at Vila do Conde in the county of Barcarena, Pará. Eletronorte's projection for energy demand for ALBRAS and ALUNORTE extend into 1995, and selected years are shown in the table.

\begin{tabular}{|c|c|c|c|c|}
\hline \multirow[b]{2}{*}{ ALUMAR (ALCOA) } & $\begin{array}{l}\text { Aluminum } \\
\text { Alumina (tpy) }\end{array}$ & $\begin{array}{l}1984 \\
\text { MWh }\end{array}$ & $\begin{array}{l}1987 \\
M W h\end{array}$ & $\begin{array}{l}1990 \\
\text { MWh }\end{array}$ \\
\hline & 400,000 & - & - & $2,619,200$ \\
\hline ALBRAS & 320,000 & 343,130 & $2,652,870$ & $5,116,540$ \\
\hline ALUNORTE & 800,000 (Alumina) & ) 178,700 & 178,700 & 178,700 \\
\hline AMSA & Railroad & 90,000 & 126,000 & 162,000 \\
\hline
\end{tabular}


A town for 70,000 persons is being constructed at about $4 \mathrm{~km}$ from the factory sites of Albras and Alunorte. Somewhat farther away, between Barcarena and Vila do Conde a farm colony is planned to supply vegetable and poultry for the new town. Considerable effort has gone into the planning of this project to insure its viability. Without Tucuruí energy this project could hardly be organized. Energy dependence may attract other resource utilizers into the region. Whether all of these will make good environmental citizens is a question not to be answered here, but it is a point that is no longer ignored in the region.

\section{V - "REPRESSED DEMAND" - SOME THOUGHTS}

If the absence of reliable energy sources kept productive activities from making effective use of the region's physical resource base, the introduction of and access to a dependable energy supply will allow changes in economy and society that were previously unavailable in the region. This will endow the region with a measure of autonomy

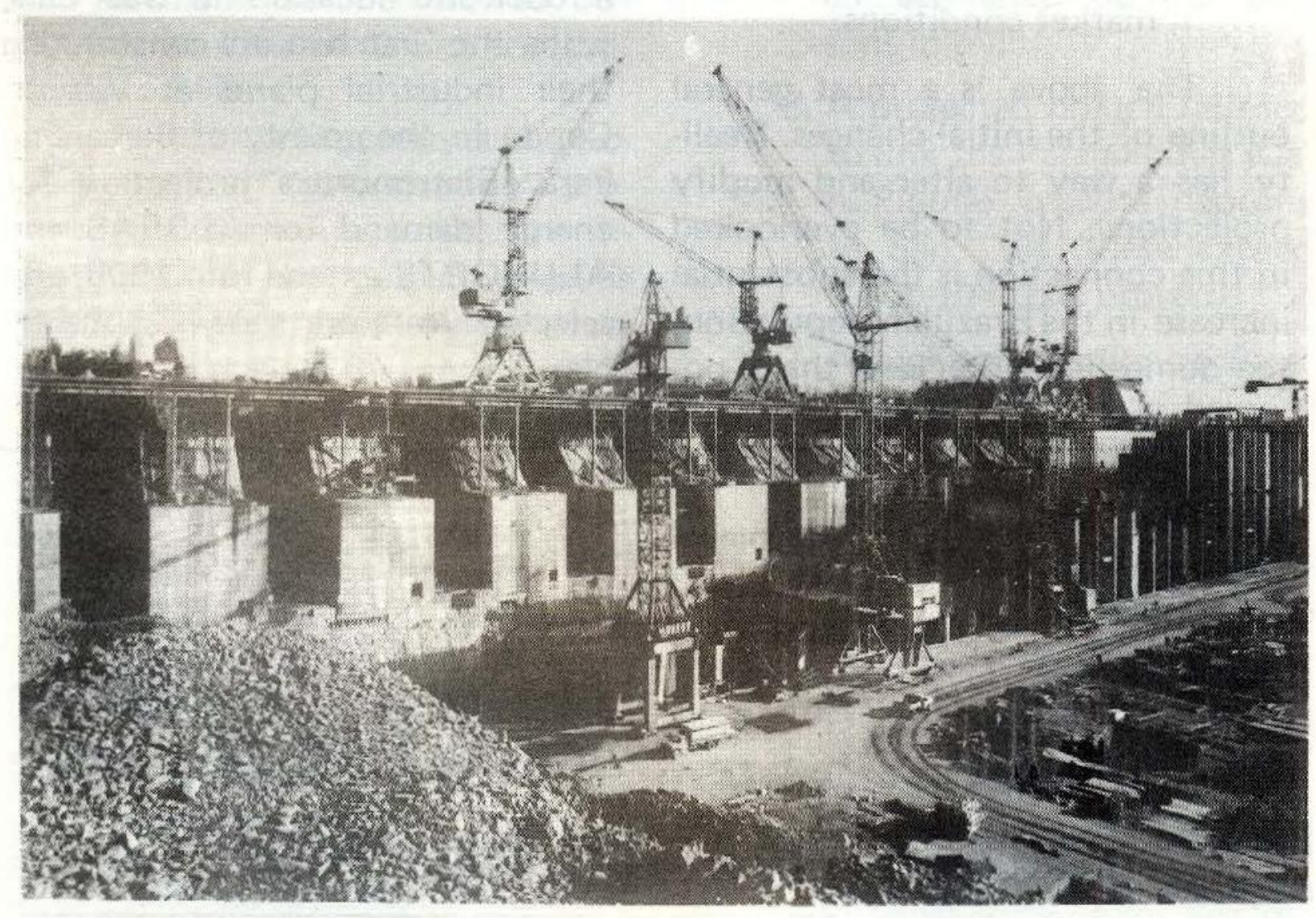

5. Tucuruí - Powerhouse - 1982 - first phase segment for 12 turbines. The second unit will be built after Santa Isabel and Carolina Dams are completed. (Photograph by Frances Sternberg). 
it enjoyed briefly during the years when rubber ruled. It is within the perspective of current planning to anticipate an end to the energy shortages that stifled possible expansion in the economic sector. "Repressed Demand" in the near future will grace graphs, contributing to an explanation why change arrived slowly in the region and arrested the "interiorization" process in general.

Even before Tucuruí energy becomes available, the repressed demand for Belém had been breached by linking the region with Sobradinho on the São Francisco in the second half of 1981. The energy is moved via a $500 \mathrm{kv}$ line out of Sobradinho that passes via Boa Esperança, hence to Imperatriz, Marabá, Tucuruí, Vila do Conde, to Belém. In the future this will be a two-way energy route that measures now $1650 \mathrm{~km}$, but its link to Recife and Salvador will have to be included then. This line has effectively freed Belém and the other urban centers from costly thermal power that was available in very inadequate amounts. By increasing the region's energy supply, notable changes in the local economy can be anticipated.

Eletronorte's market analysis for Pará State for the 1980-1995 years projects energy consumption

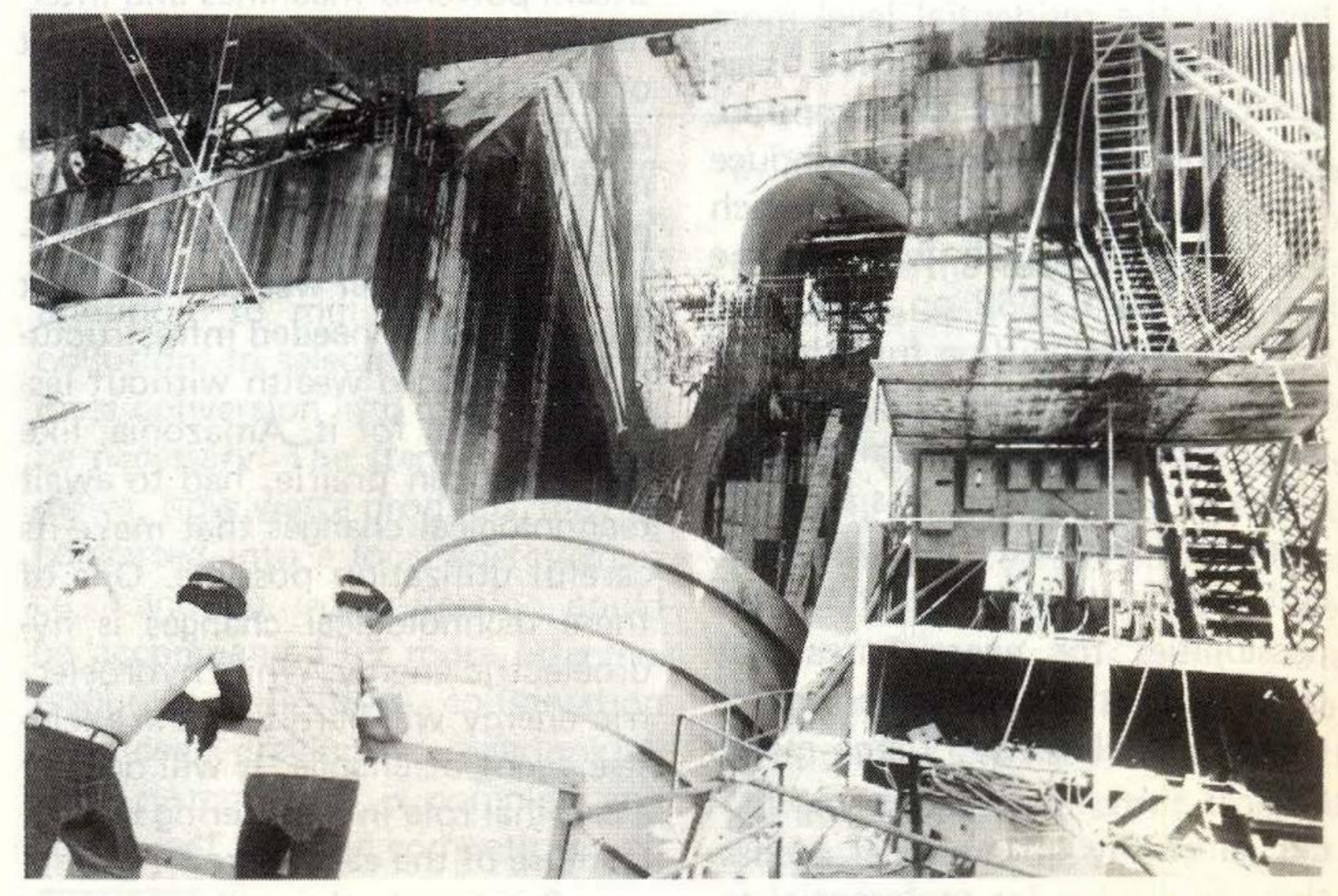

6. Tucuruí - Penstock and infrastructure 1982 - maximum potential $332 \mathrm{MW}$ per turbine. (Photograph by Frances Sternberg). 
rates to advance in excess of $10 \%$ per year(6) (Eletronorte, 1980). Instailation of thermal facilities in 1977 and 1978, which increased Belém's installed thermal plants to 230 MW by 1979 , were immediately absorbed in the local market, confirming the "repressed demand" condition reported for the Belém metropolitan region. Even as energy production increased, the reliability of the system did not improve at a corresponding pace as the complaints about irregular energy supplies and interruptions of services continued at a high rate (Eletronorte, 1980). Energy consumption is increasing sharply on a per capita basis and for a growing population. At the residential level more appliances of more intensive usage foster higher energy consumption. Increasing petroleum costs induce heavy machinery users to switch to electricity which will become apparent from 1982 on, when the Sobradinho-Belém line furnishes up to $800 \mathrm{MW}$, or more than double the amount available from thermal plants in 1979/80. At this juncture "repressed demand" may decrease, and once Tucuruí comes on stream, possibilities for energy uses may open that stimulate expansion in the industrial sector. Large metallurgical firms that require big blocks of energy in industrial processing are eligible for preferential tariffs. These tend to be $15 \%$ or so below the standard rate/kwh. This may well accelerate the demand for energy in region and speed such future projects as Carolina, Marabá, and others on the Tocantins.

VI-HYDROELECTRIC ENERGY AND THE INTERIORIZATION PROCESS: CLOSING OBSERVATIONS

The economic activities that have been historically identified with Brazilian Amazonia required no inanimate energy. Extraction of forest products was managed with manual labor, so was placer mining. Movement of products was essentially water-borne in the region. Steamboats were introduced into the region in the mid-19th century. Steam-powered machines and internal combustion motors became part of doing things in the context of time and space without conferring a measure of autarchy upon the region. Brazil's Amazon region in spite of its physical wealth could not mount a much needed infrastructure. It produced wealth without lasting benefits for it. Amazonia, like the American prairie, had to await technological changes that make its careful utilization possible. One of these technological changes is hydroelectric energy. While hydroelectric energy will hardly be the exclusive agent of change, it will occupy a cardinal role in re-ordering the human use of the earth here.

Some of the other energy sources that could supplement hydroelectric energy may be derived from such diverse sources as solar, 


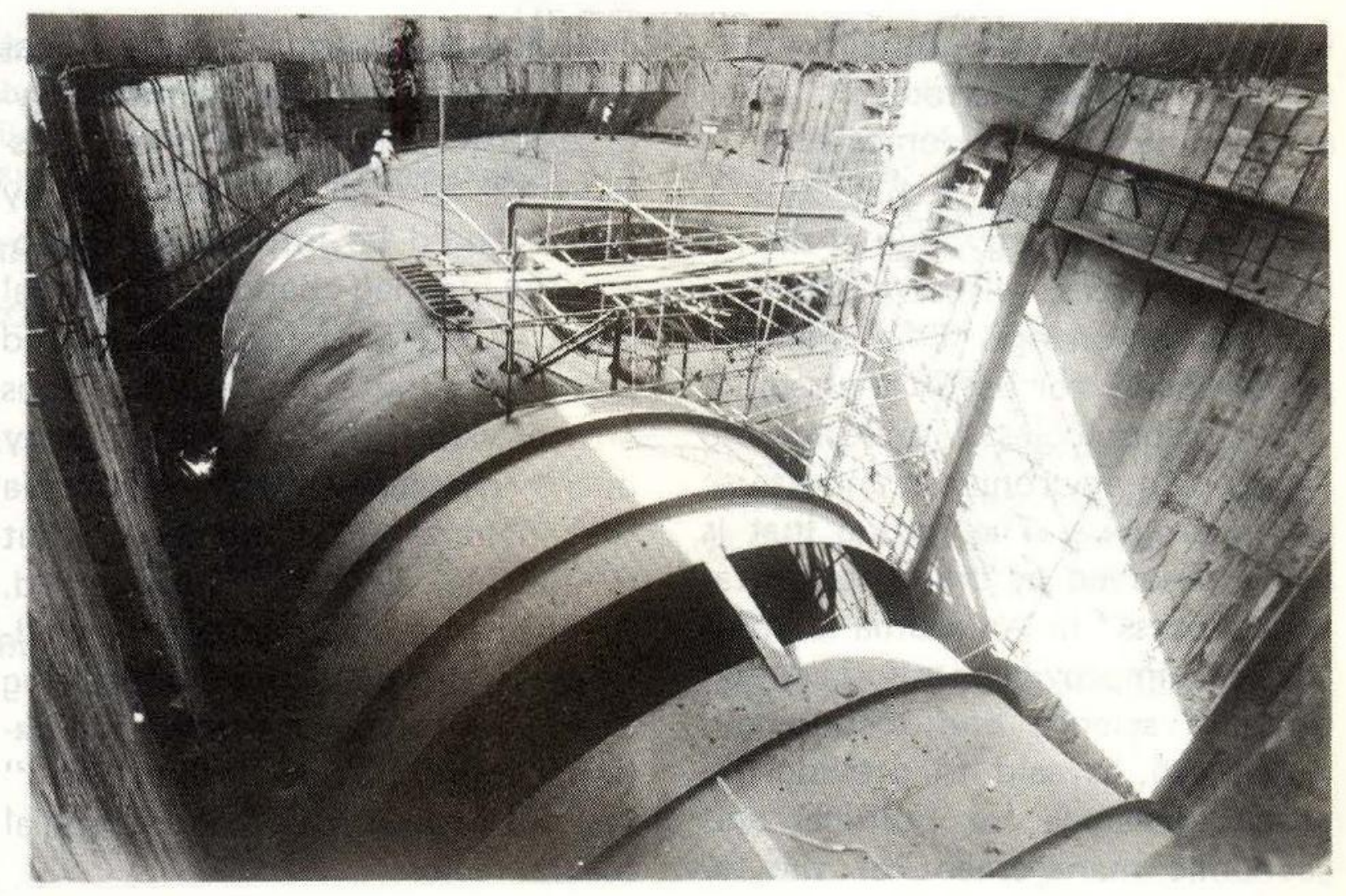

7. Tucurui - Penstock and caracol mostly in place, 1982. (Photograph by Frances Sternberg).

eolian, but especially bio-mass resources. It is the latter that are plentiful, but these need special attention to minimize waste and pollution. In selected instances biomass conversion into methanol may be necessary. The stems of jute and malva, now waste products, may be converted into a local energy source. Land-use intensification could be accompanied by more effective resource utilization, conservation practices previously overlooked. Any system that is complex and costly will find the competition wi- th hydroelectric energy a challenge.

The Belém-Brasília road proved to be the land bridge between Amazonia and the rest of Brazil. Tucuruí will provide the energy link between Eastern Amazonia and the rest of the nation. (4) Resource availability changes perceptions and perceptions create opportunities where these proved elusive previously. Tucuruí thus turns into a major stimulant for change; it makes possible what seemed distant. It creates reality in a setting that was vailed in the distant, pristine past.

(4) It would be hasty to think that much of the area west of the Tapajos and Trombetas would be part of this process. Large petroleum finds would hasten the process, but infrastructure formation would still be measured in decades. 
In practice, Amazonia is neither distant nor very mysterious. It is understanding how to domesticate it without destroying it that counts. Hydroelectric energy, one of the region's resources, will serve as an instrument of change. This is appropriate energy for use in the region. Other technologies suitable for the Amazonian environment and its use are in progress. The timing that is being observed in the "interiorization process" in Amazonia is influenced by improvements and adaptations in science and technology, which can be said to provide the needed leverage for political and economic management of the region.

In harnessing the necessary energy, the federal government via Eletrobras-Eletronorte, has created a new context to which local and national interests are actively responding as previously outlined. Though much of the initial energy output of Tucuruí will enter major projects, especially metallurgical production and rail services, more local activities stand to gain from these changes, too. Rural electrification will enter the region and its role awaits assessment. It may provide the much needed domestication of the land and conservation of the agricultural resource base. Even as hydroelectric projects, flood land, substantial areas in certain projects, the opportunities that become available because of it overshadow the inevitable inconvenien- ces. The plans for Amazonia that are actively fostered, without hydroelectric energy would be arrested until another economic energy source could be introduced to power the planned changes. The social costs of such interruptions would be so large, that such considerations are not viable. Hydroelectric energy opens perspectives on Amazonia that invite a rethinking about what is possible, desirable and needed. Brazilians have recognized the challenges and tasks and are addressing them with prudence to serve the national interest "now." The "then" has not proven itself too beneficial for the region.

\section{Resumo}

As atividades econômicas que têm sido historicamente identificadas com a Amazônia brasileira não exigiam energia de fonte "inanimada". O extrativismo vegetal é trabalho braçal, assim como a garimpagem. As máquinas a vapor e os motores de explosão se difundiram com o tempo, mas não promoveram uma apreciável auto-suficiência energética da região. Apesar dos recursos naturais existentes, a infra-estrutura tão necessária à Amazônia não se implantou. Houve produção de riqueza, mas sem benefícios duráveis para a região. A Amazônia, tal como a Prairie americana, precisou esperar pelos avanços tecnológicos que facultam sua explotação diligente. Um desses avanços tecnológicos é a energia hidrelétrica. Embora a energia hidrelétrica não seja condicionador exclusivo de transmutações, ela é fator preponderante na replanificação do uso da terra pelo homem. Ela proporciona os meios básicos ao reordenamento diligente e necessário das 
terras tropicais. A energia hidrelétrica abre amplas perspectivas à Amazônia brasileira, clamando por um reexame do que é possível, desejável e necessário.

\section{REFERENCES}

CONSTRUTORA A. GUTIERREZ

1981 - Tucumã. Belo Horizonte. p. 4.

\section{ELETRONORTE}

1980 - Mercado de Energia elétrica do Estado do Pará, período 1980-95. Brasília.

IBGE p. 15.

1981 - Sinopse preliminar do Cen- so Demográfico: Rondonia-Roraima-Acre. Rio de Janeiro. 35p.

JAMES, PRESTON E.

1969 - Latin America. New York, Oddyssy.

MATOS, MEIRA

1980 - Uma Geopolítica Pan Amazônica. Rio de Janeiro, Olympio.

REIS, ARTHUR CEZAR FERREIRA

1956 - A Amazonia que os portugueses revelaram. Rio de Janeiro, SPVEA.

(Aceito para publicação em 12/6/83). 